\title{
The impact of urban concentration on countries' competitiveness and entrepreneurial performance
}

\begin{abstract}
This paper aims to elaborate the role of Jacobs-type of agglomeration effects on countries' competitiveness and entrepreneurial performance. Our research allows for a better understanding of the relationship that exists between a country's urban system, characterized by spatial agglomeration (concentration) or deglomeration (deconcentration) processes, and its competitiveness and entrepreneurial performance.

Urbanization economies refer to considerable cost savings generated through the locating together of people, firms and organizations across different industries. It has recently become an axiom that the better performance of global cities (as they are important nodes of innovation and creativity) is derived from agglomeration effects. This general assumption follows that the more concentrated an urban system of a country, the more competitive and better its entrepreneurial performance. Even though this notion has gained quick and ardent acceptance from practitioners, the related literature shows contradictory results; this has induced a heated debate in academic circles, because it has raised serious doubts about the "bigger is better" theory. We hope to contribute to this debate with our detailed analysis.

To understand the impact of urban concentration, we selected 70 countries and calculated the so-called ROXY Index measuring the degree of agglomeration or deglomeration in their urban systems. To exemplify country-level competitiveness, we applied the Global Competitiveness Index (GCI) while the Global Entrepreneurship and Development Index (GEDI) was used to demonstrate country level entrepreneurial performance. Using these indexes correlation and cluster analysis were designed to obtain understanding of the relationship between them.

Our analysis indicates that as urban concentration initially increases competitiveness, entrepreneurial performance also increases, but at a decreasing rate. Both of them eventually reaches a maximum, and then after a certain point decrease with further concentration. Therefore, the curve for this relationship is non-linear and folds back. This indicates that over- or under-concentration of the population within an urban system does not necessarily result in a better outcome. However, we should consider that a high concentration of population is only one important factor for competitiveness and entrepreneurial performance while other effects may exist.
\end{abstract}

a) Research fellow, MTA-PTE Innovation and Economic Growth Research Group, Faculty of Business and Economics, University of Pécs, H-7622 Pécs, Rákóczi út 80., Hungary. E-mail: komlosieva@ktk.pte.hu

b) Graduate research assistant, Centre for Economic and Regional Studies, Hungarian Academy of Sciences H-7621 Pécs, Papnövelde utca 22., Hungary. E-mail: pagerb@rkk.hu 
Keywords: urbanization economies, entrepreneurship, competitiveness, spatial cycles, ROXY Index.

\section{Introduction}

It was the classical economist, Alfred Marshall (1920), who first identified the main characteristics and sources of location-specific economies of scale labelled in economic literature as agglomeration or external economies. Since that time, other researchers have actively been contributing to the further development of his theory. Today it is widely accepted that agglomeration economies refer to an increasing return of scale derived from the clustering of different or, on the contrary, similar and specific economic activities. Colocating near other firms, organizations and people can result in an increased benefit from greater diversity and/or specialization. Some often mentioned reasons for these advantages are the following: (1) market size effect (demand side), (2) local skilled labour pool effect (supply side), (3) local non-traded inputs (e.g. special business services), as well as (4) tacit knowledge and spillover effects. Clustering of firms together at a location implies frequent personal contacts and social ties among local actors that facilitate the circulation of information among them. Hence, intense knowledge spillovers are fostered by the proximity of firms, thereby promoting their innovation activity, and ultimately resulting in higher profit. Local non-traded inputs refer to peculiar products or services whose provision can be very expensive. However, if there are many firms located together, the cost of such special products or services can be dispersed among them. Co-locating of many firms also goes hand in hand with the accumulation of a skilled workforce. In many sectors, the cost of searching and (re)training people can be extremely high and timeconsuming, particularly in a rapidly changing environment. Therefore, easy access to a pool of skilled labour also benefits firms (Duranton-Puga 2004, Rosenthal-Strange 2004, Puga 2010, McCann 2013). Even though agglomeration economies can be classified in several ways, typically three major categories are distinguished: (1) benefits of localization economies (Marshall - Arrow - Romer externalities) are derived from the agglomeration of specialized firms across the same industrial sector, (2) urbanization economies (Jacobs' externalities) refer to cost savings generated through the locating together of people and firms across different industries, and (3) internal economies of scale results in a significant return because of the size of the firms (Parr 2002, McCann 2013). In this paper, we solely study the impact of urbanization economies on countries' competitiveness and entrepreneurial performance.

Nowadays, there is a widely held view that global cities and large urban areas perform better and grow faster than the others. First of all, the appearance of globalization, new information and communication technologies have given rise to the recognition that metropolis are the 'space of flows' as they are important nodes of innovation and creativity (Castells 1996). According to a large extent of the literature, the better performance of big cities can be explained by the advantages of agglomeration economies. Several theoretical and empirical studies have affirmed that agglomerations associated with a high density of economic activity does matter for productivity and economic growth (e.g., Chinitz 1961, Glaeser et al. 1992, Ellison and Glaeser 1997, Ciccone and Hall 1996, Ciccone 2002, Henderson 2003a, Rosenthal-Strange 2003). Studies dealing with urbanization economies 
ascertain that a doubling of city size results in a productivity gain of between 2 and 8 percent (see overview from Vreeker et al. 2009).

This general assumption follows that the more concentrated an urban system of a country, the more competitive and better its entrepreneurial performance. For instance, in his well-known theoretical general equilibrium model, Krugman explained the initial spatial concentration processes of economic activities by identifying the main reasons, and introduced a new stream in spatial economic science, the New Economic Geography (NEG). NEG interprets agglomeration economies as the outcome of three reasons: (1) increasing returns, (2) trade costs and (3) the demand for manufacturing products. Krugman's theory implies that production is prone to concentrate in a few regions, which will become populous and competitive (Krugman 1991, 2009). Despite the remarkable novelty of Krugman's theory, it does not give any satisfying answer about divergent regional growth (Acs-Varga 2002). Also, findings from empirical studies indicate the positive effect of urban concentration on entrepreneurial performance mainly measured by new firm formation rates. Highly populated urban areas offer more opportunity for entrepreneurial success, because they can provide firms with a large consumer base, relatively cheap physical infrastructure, tacit knowledge, special services or a skilled workforce., therefore new firms prefer highly urbanized areas (Reynolds et al. 1994, AcsArmington 2004, Van Stel-Suddle 2008, Knoben et al. 2011).

The 'bigger is better' notion has gained quick and ardent acceptance from practitioners, particularly from policymakers. Consequently, many EU territorial strategic concepts support the same view, viz. metropolitan areas are the most important drivers of European competitiveness, even if only a few studies unambiguously prove a positive contribution from agglomeration effects on economic growth. In fact, the majority of studies have highlighted contradictory results. De facto; there are some papers that support the view that urbanization economies tend to increase with the size of the city and they have a positive impact on economic growth; on the other hand, other studies have found no clear evidence that urbanization economies would generate growth (David et al. 2013). Then, there are some other studies that may explain these contradictory results. Findings of these papers refer to the negative effects of urban concentration, such as higher costs of skilled labour or higher rent for land, environmental contamination and severe congestion. Recent studies suggest that spatial competition (for qualified labour and other inputs), as a centrifugal force, can restrain the above-mentioned positive effect of urban concentration, possibly leading to a decrease in start-up rates and productivity growth (Rizov et al. 2012). Henderson (2003b) has estimated the impact of urbanization and urban concentration on productivity growth at the country level for the period between 1960 and 1990. According to his results, productivity growth is not strongly affected by urbanization, because "urbanization is not a growth stimulus per se, is it a by-product", but there is a "best degree of urban concentration in terms of maximizing productivity growth that varies with the level of development and country size" (Henderson 2003b, p. 50). Consequently, both over- and under-concentration have negative effects on growth: "City size affects positively the degree of local information spillovers, which interactively affects local knowledge accumulation, promoting productivity growth. However, cities of extensive size draw resources away from investment and innovation in productive activity to try to maintain the quality of life in a congested local environment." (Henderson 2003b, p. 67). According 
to Duranton and Puga (2001, p. 1454) cities can be conceived as areas "facilitating search and experimentation in innovation". They also found evidence that under-sized cities have too little experimentation affecting productivity nationally, while over-sized cities waste excessive amounts of resources on other activities, which, drawing resources away from experimental activities, accordingly also inhibiting growth (Henderson 2003b). David et al. (2013) have systematically tested the relationship between city size (urban concentration) and the economic performance of cities in the European context. Their analysis also confirmed that the comparative advantage of cities also depends on the country in which they are located: "In highly developed and densely urbanized areas, congestion effects might counteract the advantages of agglomeration. ... Hence, it may be that, in the dense Western part of Europe more than in the rest of Europe, the performances of the cities are more linked to their economic structures, their heritage, and the quality of their governance than to their size and centrality" (David et al. 2013, p. 249). CastellsQuintana and Royuela (2014), in their study, explain that agglomeration (as urban concentration) fosters growth particularly in low-income developing countries, while urbanization has a positive effect on high-income developed countries. Since the large cities in Europe are highly urbanized areas, the positive link between urbanization and economic growth has already vanished. At the same time, dis-economies as congestion, pollution or high housing prices may have a negative effect. Consequently, economic growth in developed countries has been observed in small- and medium-sized cities, because of their intense urbanization: "among the rich countries, twelve out of fifteen most entrepreneurial cities are small to medium-sized cities...” (McCann-Acs 2012, p. 23).

In our study, we focus on the understanding of the relationship between a country's urban system characterized by spatial agglomeration (concentration) or deglomeration (deconcentration) processes and its competitiveness, as well as its entrepreneurial performance. The innovative component of our paper is that we demonstrate the impact of urbanization economies classified by the four stages of the spatial-cycle path on economic performance; and using a large sample of countries, a long time span and a method that has never been used for such purpose. Our results are consistent with other studies' findings related to the emerging literature on the limits of agglomeration.

We selected 70 countries and calculated the "ROXY Index", measuring the degree of agglomeration or deglomeration in their urban system. To exemplify country-level competitiveness, we applied the Global Competitiveness Index (GCI) while the Global Entrepreneurship and Development Index (GEDI) was used to demonstrate country level entrepreneurial performance.

The remainder of this paper is organized in the following fashion. First, the descriptions of the employed indexes (GEDI, GCI and ROXY) are reviewed (Section 2.1). We then describe the data and analysis methodology in Section 2.2. Our results are reported in Section 3. Finally, a concluding summary and discussion is provided in Section 4.

\section{Data and methodology}

In this section, we summarize the applied indexes and methodology. We employed three indexes for the analyses: (1) the Global Competitiveness Index (GCI) as a comprehensive tool to characterize country-level competitiveness, (2) the Global Entrepreneurship and 
Development Index (GEDI) as a composite indicator of entrepreneurship performance, and (3) as a third index the ROXY Index, which indicates the direction and size of population changes (concentration or deconcentration processes) within an urban system. We conducted correlation and cluster analysis to understand the relationship between urban concentration/deconcentration trends and economic performance.

\section{Measuring country-level competitiveness and entrepreneurship}

Since 2004, the yearly published Global Competitiveness Report - developed by the World Economic Forum (WEF) - ranks countries according to their competitiveness based on a composite indicator, the "Global Competitiveness Index" (GCI). According to the WEF, competitiveness can be defined "as the set of institutions, policies, and factors that determine the level of productivity of a country" (Schwab 2013, p. 4). Therefore, GCI builds up from many different indicators that characterize the institutions, productivity or policies of countries. Altogether 12 pillars are created from the identified set of indicators, which can be divided into three sub-indexes": "basic requirements"(4 pillars), "efficiency enhancers" (6 pillars) and "innovation and sophistication factors" ( 2 pillars). The three subindexes are calculated by using weights that express the development level of a country's economy. Three development categories are used by WEF: factor-driven, efficiencydriven and innovation-driven economies. The involved countries are grouped into five groups, which are determined by the three development levels and two transition stages. Finally, the GCI Index is composed of the weighted average of the three sub-indexes. In our research, we used data derived from several GCI reports over the period 2006-2014.

The Global Entrepreneurship Development Institute lead by Zoltan J. Acs and László Szerb developed the Global Entrepreneurship Index (GEDI). The GEDI Index is a composite index that measures productive entrepreneurship in a multidimensional way. It examines the connection between entrepreneurship and economic development and provides policy recommendations regarding economic policies (Szerb et al. 2013). The basic idea of the GEDI Index is based on the theory of the National System of Entrepreneurship that "(...) is the dynamic, institutionally embedded interaction between entrepreneurial attitudes, ability, and aspirations, by individuals, which drives the allocation of resources through the creation and operation of new ventures" (Acs et al. 2014 , p. 479). The index builds on individual data derived from the Global Entrepreneurship Monitor (GEM) Adult Population Survey. It focuses not only on the process of business creation but also captures the qualitative aspects, the 'institutional context' of the country. The index consists of three sub-indexes (attitudes, abilities, aspirations), and each sub-index has four or five pillars. The GEDI pillars are determined by a complex method and indicate the combined effect of individual and institutional data. $^{2}$

1 The whole descriptions of GCI sub-indexes and pillars are available in the 2013-14 edition of the Global Competitiveness Report: http://www3.weforum.org/docs/WEF_GlobalCompetitivenessReport_2013-14.pdf

2 The whole description of GEDI sub-indexes and pillars are available in the latest GEDI book: Zoltan J. Acs et al. (2013): Global Entrepreneurship and Development Index. Edward Elgar Publishing. 
To express urbanization economies, we calculated the ROXY Index ${ }^{3}$, which is "an indicative instrument to quantitatively identify the major stages of the spatial cycles. This index can be used in conducting both of the intra- and inter-city analysis to study the spatial agglomeration and deglomeration processes" (Fukatsu - Kawashima et al. 1999, p. 395). The ROXY Index captures the effect of migration through the periodic change of the population. It measures the change in population by a weighted average growth ratio and by a simple average growth ratio (see the formula below).

$$
\text { ROXY Index }=\left(\frac{W A G R_{t, t+1}}{\operatorname{SAGR}_{t, t+1}}-1,0\right) * 10^{4}=\left\{\frac{\sum_{i+1}^{n}\left(x_{i}^{t} * r_{i}^{t, t+1}\right)}{\sum_{i=1}^{n} x_{i}^{t}} * \frac{n}{\sum_{i=1}^{n} r_{i}^{t, t+1}}-1,0\right\} * 10^{4}
$$

where: $\mathrm{x}_{\mathrm{i}}^{\mathrm{t}}=$ population of city " $\mathrm{i}$ " in year " $\mathrm{t}$ ", $\mathrm{r}^{\mathrm{t}, \mathrm{t+1}}{ }_{\mathrm{i}}=$ annual growth ratio of population in city " $\mathrm{i}$ " for the period between years " $\mathrm{t}$ " and " $\mathrm{t}+\mathrm{l}$ ", which is defined as the " $\mathrm{k}$ "th root of $\mathrm{x}_{\mathrm{i}}^{\mathrm{t}+\mathrm{k}} / \mathrm{x}_{\mathrm{i}}^{\mathrm{t}}, \mathrm{n}=$ number of cities, WAGR $\mathrm{t}_{\mathrm{t}+1}=$ weighted average of annual growth ratios of population " $\mathrm{n}$ " cities for the period between years " $\mathrm{t}$ " and " $\mathrm{t}+1$ ", which is equal, in the case where population level of each city is used as a weighting factor, to $\sum\left(x_{i}^{t} * r_{i}^{t, t+1}\right) / \sum x_{i}^{t}$, $\mathrm{SAGR}_{\mathrm{t}, \mathrm{t}+1}=$ simple average of annual growth ratios of population in " $\mathrm{n}$ " cities for the period between years " $\mathrm{t}$ " and " $\mathrm{t}+1$ ", which is equal to

$$
\sum r_{i}^{t, t+1} / n
$$

Marginal value of the ROXY Index ( $\triangle \mathrm{ROXY})$

$$
\triangle R O X Y=\frac{R_{O X Y} \operatorname{Index}_{(t+1, t)}-R_{O X Y} \operatorname{Index}_{(t, t-1)}}{C f}
$$

where: ROXY Index $(t+1, t)=$ the value of ROXY Index for period " $t$ ", $\operatorname{ROXY~Index~}_{(t, t-1)}=$ the value of ROXY Index for period "t-1", Cf = the difference between the mid-point time for " $\mathrm{t}$ " period and the mid-point time for "t-1" period (Source: Kawashima et al. 1997, p. 221 and Fukastu - Kawashima 1999, p.407.).

The index is based on the spatial-cycle hypothesis originally conceptualized by Klaassen $(1979,1981)$. Klaassen differentiated four stages of the spatial-cycle path: Stage 1 - Accelerating concentration, Stage 2 - Decelerating concentration, Stage 3 Accelerating deconcentration and Stage 4 - Decelerating deconcentration (Kawashima et al. 1997). The first version of the ROXY Index was published in an empirical study written by Kawashima (1978). Since then, the index has been developed further and used in numerous empirical studies to identify the spatial agglomeration - deglomeration phenomena associated with the changes in population or other social and economic variables (see Kawashima 1982, 1985, 1986, Hirvonen et al. 1997, Fukatsu-Kawashima 1999).

According to the size and direction of the ROXY Index, four hypothetical stages of the spatial-cycle process can be distinguished. The positive value of the ROXY Index indicates concentration while the negative value shows deconcentration. The direction of change depends on the value of $\triangle \mathrm{ROXY}$ : if it is positive, there is an accelerating concentration or decelerating deconcentration; if it is negative, it indicates an accelerating deconcentration or decelerating concentration (Table 1). 
The characteristics of different stages of urbanization

\begin{tabular}{c|c}
\hline Stages of urbanization & The size and direction of change \\
\hline AC (accelerating concentration) & positive ROXY value, $\Delta$ ROXY positive \\
\hline DC (decelerating concentration) & positive or negative ROXY value, $\Delta$ ROXY negative \\
\hline DD (decelerating deconcentration) & negative or positive ROXY value, $\Delta$ ROXY positive \\
\hline AD (accelerating deconcentration) & negative ROXY value, $\triangle$ ROXY negative \\
\hline Source: own compilation based on Kawashima et al. 1997.
\end{tabular}

There are two crucial points in the computation of the ROXY Index: (1) the length of the examined period and (2) the number of cities that are involved in the examination. Therefore, we tried to find a rule or concept that could help us identify the most important cities of each examined country. However, data like GDP, which could represent the most important cities in a country, are available for only a few countries at the city level. After reviewing some of the relevant literature (see Gabaix 1999; Eeckhout 2004; Tabuchi et al. 2005; Czaller 2012), we realized that although the problem of determining the adequate number of cities is known, no clear solution exists. Therefore, we decided to analyse three cases and conducted the analysis for the first 20,30 and 40 most populated cities of the 70 countries. It was important to be aware that the sample contained very different countries with regard to their size. Thus, examining an urban system with less than 20 cities was considered too small; on the other hand, in the case of some countries, it was not possible to examine their urban systems with more than 40 cities, because data were not available. The three mentioned cases may also serve as a robustness check of the results.

The other important factor to calculate the ROXY Index is the time period in which the index indicates the agglomeration or deglomeration trends. Therefore, we used the three latest available data of city populations. Thus, we created two periods $\left(\mathrm{ROXY}_{\mathrm{t}}\right.$ and $\mathrm{ROXY}_{\mathrm{t}}$ 1) and calculated the $\triangle R O X Y$ that shows the direction and scale of the change. Our original idea was that the time periods used by the GEDI/GCI Index would be considered by the calculation of the ROXY ${ }_{t}$ and ROXY $\mathrm{t}_{\mathrm{t}-1}$ indexes. However, because of data availability, the first or last years, and also the lengths of the periods were not the same for the different countries (see Appendix Table A1).

Originally, we planned to carry out analyses for all the countries involved in the GEDI research during the examined period. It was altogether 76 countries, but we excluded some of them due to the lack of city population data. Thus, we could involve 70 countries. Our country set contains both developed and developing nations. Because of the lack of former city population data, it was not possible to calculate $\mathrm{ROXY}_{\mathrm{t}-1}$ for some countries (Jordan, Malaysia, Portugal and South Africa), hence we had to exclude them from the later examinations. In the case of the United Arab Emirates, city population data are available only for its nine biggest cities; therefore, only the ROXY20 was calculated for the available cities of the United Arab Emirates (UAE). 


\section{Method}

To examine the intensity and direction of the relationships among the indexes, we conducted correlation analysis. We carried out the correlation analyses separately for the two indexes - GCI and GEDI - using the three versions of the ROXY Index (ROXY20, ROXY30 and ROXY40). The analyses were not limited to the main indexes alone. We also analysed the relationships between the ROXY Index and the different sub-indexes of GCI and GEDI. Furthermore, those sub-indexes of GCI and GEDI that showed the highest correlation with the ROXY Index were also examined.

As a first step, we checked the characteristics of our descriptive statistics. GCI and GEDI did not require any data transformations, but a relatively high skewness was discovered considering the ROXY Index. We managed this problem with a transformation process. Many data transformation processes were checked that might solve the problem of skewness. The results of the correlation analysis with different transformation processes did not show significant differences. Hence, we decided to apply the Box-Cox transformation method, in the same way as Annoni-Kozovska (2010). Finally, the transformed ROXY Index data were rescaled to a scale from 0 to 10 .

We endeavour to use not only the annual values of GEDI and GCI but also to represent the changes in their values during a given period as well. Therefore, we calculated the average value of both indexes for the whole period (GCI_AVE and GEDI_AVE). To catch the changes within the examined period, the changes from year to year were calculated and averaged for each country as well (GCI_CH and GEDI_CH). Finally, we multiplied the 'average values' with the 'change values' in the case of both indexes (GCI_AVG_CH and GEDI_AVG_CH). Then we rescaled both modified indexes to a scale from 0 to 10 .

As a next step, K-means cluster analysis was conducted. First, the observed outliers were excluded from the analysis. The examination started with 66 countries in the case of ROXY20 (no available / t-1 / data for Jordan, Malaysia, Portugal and South Africa) and 65 countries in the case of ROXY30 and ROXY40 (no available / t-1 / data for Jordan, Malaysia, Portugal and South Africa and UAE). We used the original and transformed ROXY indexes in the cluster analysis as well. We tested different numbers of clusters (2, $3,4,5$ and 6 groups). However, the results of the ANOVA test (the optimal F- and significance-values) indicated the need to create 3 clusters in the case of GCI with the original ROXY Index and 4 clusters with the transformed ROXY values, while countries were classified into 4 groups in the case of the GEDI Index using the transformed ROXY values. The tests proved that the groups are significantly different from each other at every significance level.

\section{Results}

\section{Results of the examination: ROXY and GCI indexes}

In this sub-section, we examine the intensity and direction of the relation between the GCI Index and the three version of ROXY Index. Table 2 contains both the original ROXY indexes for different pools of cities (ROXY20, ROXY30 and ROXY40) and also the three Box-Cox transformed and rescaled ROXY indexes (ROXY_BOXCOX_10). 
According to the correlation analysis, there is a positive relationship between the ROXY and the GCI Index, but the intensity of this relationship is quite moderate, and it is significant only with the Box-Cox transformed ROXY indexes. The ROXY40_BOXCOC_10 variable and the GCI Index show the strongest correlation coefficient $(\mathrm{r}=0.321)$. If we analyse the relationship between the ROXY Index and the three sub-indexes of GCI (BASIC - GCI Basic sub-index, EFF - Efficiency sub-index, INN - Innovation sub-index), the strongest correlation can be observed between the ROXY Index and the GCI Efficiency sub-index, but only a loose connection can be confirmed among them $(\mathrm{r}=0.350)$. We can assume that concentration or deconcentration of the population within an urban system has a moderate effect on efficiency (Table 2). To investigate this presumption, we detach the relationship between the transformed ROXY Index and the different pillars of the GCI Efficiency sub-index (Table 3).

Besides the intensity of the connection, the direction is also very important. A positive correlation coefficient between the ROXY Index, the GCI Index and its sub-indexes means that the more concentrated the population within a country's urban system, the higher the value of the GCI Index. Higher GCI value refers to the higher competitiveness of the country.

Table 2

The correlation coefficients between the GCI Index, its sub-indexes and ROXY Index

\begin{tabular}{l|c|c|c|c}
\hline $\begin{array}{c}\text { ROXY INDEX } \\
\text { (original and transformed) }\end{array}$ & GCI_(AVG_CH) & BASIC_(AVG_CH) & EFF_(AVG_CH) & INN_(AVG_CH) \\
\hline ROXY20 & 0.187 & 0.187 & 0.220 & 0.139 \\
ROXY30 & 0.216 & 0.211 & $0.242^{\text {a) }}$ & 0.154 \\
ROXY40 & 0.218 & 0.210 & $0.241^{\text {a) }}$ & 0.153 \\
ROXY20_BOXCOX_10 & 0.221 & 0.223 & $0.267^{\text {a) }}$ & 0.183 \\
\cline { 1 - 1 } ROXY30_BOXCOX_10 & $0.295^{\text {a) }}$ & $0.279^{\text {a) }}$ & $0.347^{\text {b) }}$ & $0.261^{\text {a) }}$ \\
\cline { 1 - 2 } ROXY40_BOXCOX_10 & $0.321^{\text {b) }}$ & $0.305^{\text {a) }}$ & $\mathbf{0 . 3 5 0}^{\text {b) }}$ & $0.292^{\text {a) }}$ \\
\cline { 1 - 2 } & & & &
\end{tabular}

Note: BASIC = GCI "Basic" sub-index, EFF = GCI "Efficiency" sub-index, INN = GCI "Innovation" sub-index. a) Correlation is significant at the 0.05 level (2-tailed). b) Correlation is significant at the 0.01 level (2-tailed).

Source: own calculations.

The correlation coefficients between the pillars of GCI Efficiency sub-index and ROXY Index

\begin{tabular}{l|c|c|c}
\hline $\begin{array}{c}\text { Pillars of GCI } \\
\text { Efficiency sub-index }\end{array}$ & ROXY20_BOXCOX_10 & ROXY30_BOXCOX_10 & ROXY40_BOXCOX_10 \\
\hline HT_(AVG_CH) & $0.284^{\text {a) }}$ & $\mathbf{0 . 3 6 2}^{\text {b) }}$ & $\mathbf{0 . 3 6 3}^{\text {b) }}$ \\
MEFF_(AVG_CH) & 0.148 & $0.255^{\text {a) }}$ & $0.283^{\text {a) }}$ \\
LEFF_(AVG_CH) & 0.298 & $\mathbf{0 . 4 0 4}^{\text {b) }}$ & $\mathbf{0 . 3 8 2}^{\text {b) }}$ \\
FIN_(AVG_CH) & 0.112 & 0.192 & 0.206 \\
TECH_(AVG_CH) & $0.295^{\text {a) }}$ & $\mathbf{0 . 3 8 5}^{\text {b) }}$ & $\mathbf{0 . 3 9 6}^{\text {b) }}$ \\
MSIZE_(AVG_CH) & 0.143 & 0.108 & 0.095
\end{tabular}

Note: $\mathrm{HT}=$ Human capital pillar, MEFF $=$ Market efficiency pillar, LEFF $=$ Labour efficiency pillar, FIN = Financing pillar, $\mathrm{TECH}=$ Technological readiness pillar, MSIZE $=$ Market size pillar, $\mathrm{AVG}=$ average, $\mathrm{CH}=$ change .

a) Correlation is significant at the 0.05 level (2-tailed). b) Correlation is significant at the 0.01 level (2-tailed).

Source: own calculations. 
Efficiency sub-index group's pillars related to human capital, market efficiency, labour productivity, financing, technology readiness and market size. Three of the pillars - Human capital, Labour efficiency and Technology readiness - show positive medium-strength correlation coefficients with the transformed and rescaled ROXY Index (Table 3). The strongest connection is shown between the GCI Labour efficiency pillar and the transformed ROXY30 ( $\mathrm{r}=0.404)$. The positive coefficient means that the higher the concentration in a country's urban system in a given period, the higher the labour efficiency, the technological readiness and the quantity of skilled human capital of the country.

As a next step, we conducted cluster analysis for each county's urban system consisting of the first most populous 20,30 and 40 cities, respectively. Determining the direction of change, we calculated the ROXY values for the previous period (t-1) to receive the $\triangle$ ROXY. We carried out the cluster analysis with different cluster numbers $(2,3,4,5$ and 6 groups). Using original ROXY values, the ANOVA analysis showed the best F-test values with 3 clusters (the interpretation of the clusters below or over 3 clusters was problematic). However, using the Box-Cox transformed ROXY values, the interpretation of 4 clusters seemed to be more appropriate (ANOVA analysis showed appropriate F-test values for both 3 and 4 clusters). Consequently, we present here the results of the cluster analysis for 3 and 4 clusters. According to the ANOVA test, the significance was lower than 0.05 , proving that the clusters in terms of the variables differ from each other. Here, we only show the results of the cluster analysis conducted between the ROXY30 and GCI index (cluster analyses with ROXY20 and ROXY40 are available in the Appendix and serve as robustness checks).

As mentioned above, using the original ROXY Index, we could distinguish three clusters (Table 4). Cluster 1 contains those countries whose urban system is characterized by a strong concentration trend represented with a high ROXY value (final cluster centre $=5.21$ ). The results show that the competitiveness of those countries in which the urban system is highly concentrated is high ( $\mathrm{GCI}$ final cluster centre $=5.33$ ). It contains 11 countries characterized by the acceleration of concentration (AC), and 29 countries characterized by the deceleration of deconcentration (DD). Cluster 2 consists of 12 countries, among them 9 characterized by the deceleration of deconcentration, but they are still in the deconcentration stage. This cluster generally contains countries in which the urban system is heading to a concentration from the deconcentration stage. This cluster is a transitional category. Cluster 3 contains those countries in which the deconcentration of the urban system is accelerating (AD, ROXY final cluster centre $=-168.86$ ). According to the results of the analysis, if deconcentration is strengthening, competitiveness will drop ( $\mathrm{GCI}$ final cluster centre $=2.63$ ).

On the other hand, using the Box-Cox transformed ROXY Index, we could identify 4 clusters of countries (Table 4). An important difference compared to the 3 cluster case is that here, if a country's urban system is characterized either by a strong concentration trend (Cluster 1) or by a strong deconcentration trend (Cluster 4), competitiveness will fall (Cluster $1-$ GCI final cluster centre $=2.77$, Cluster $4-$ GCI final cluster centre $=2.82$ ). While if the county's urban system is in a transition stage - meaning it is not so concentrated, or not so deconcentrated - competitiveness will be more outstanding (Cluster $2-$ GCI final cluster centre $=8.33$, Cluster $3-$ GCI final cluster centre $=4.57$ ). 
Results of the cluster analysis: ROXY30 - GCI index

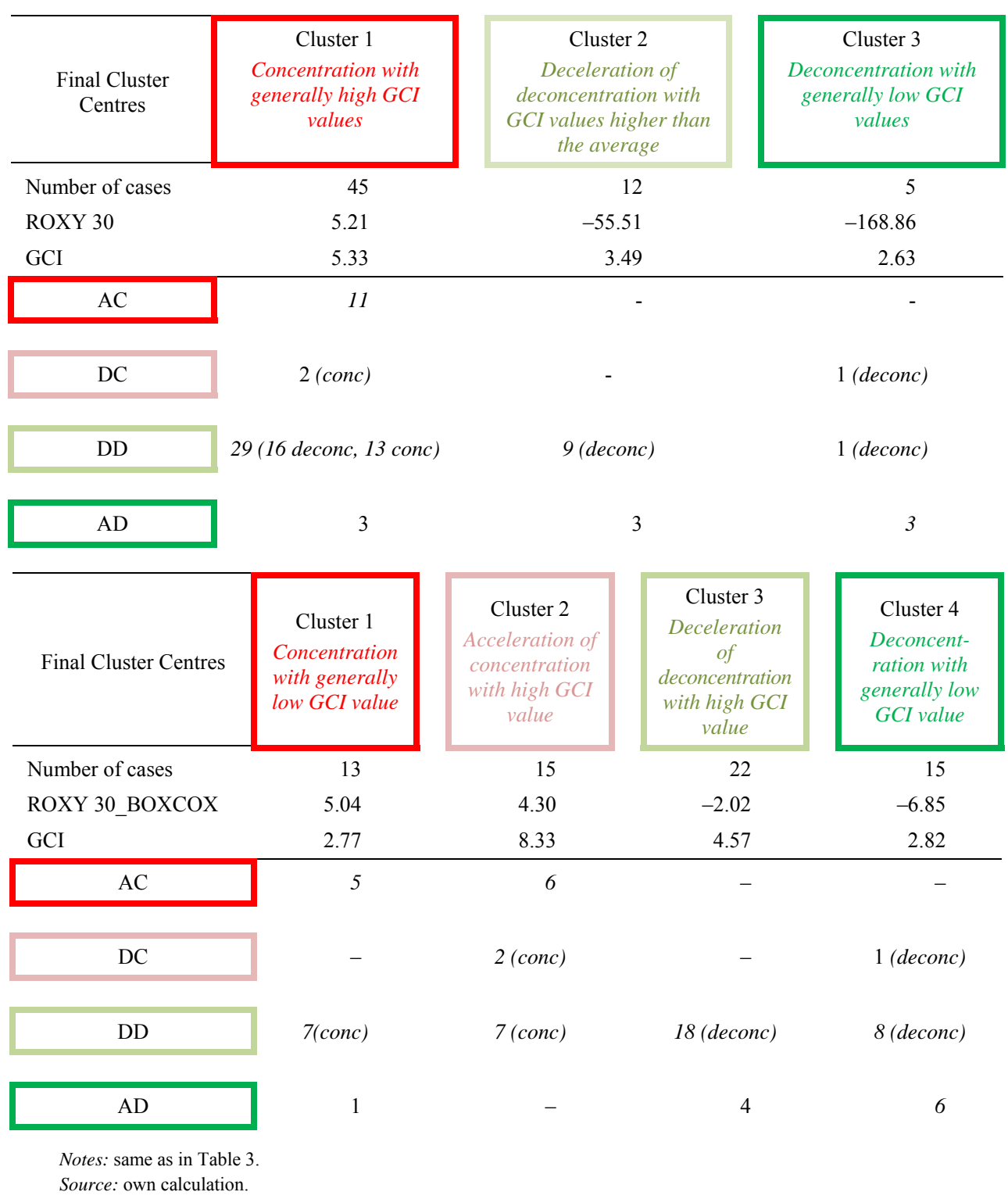




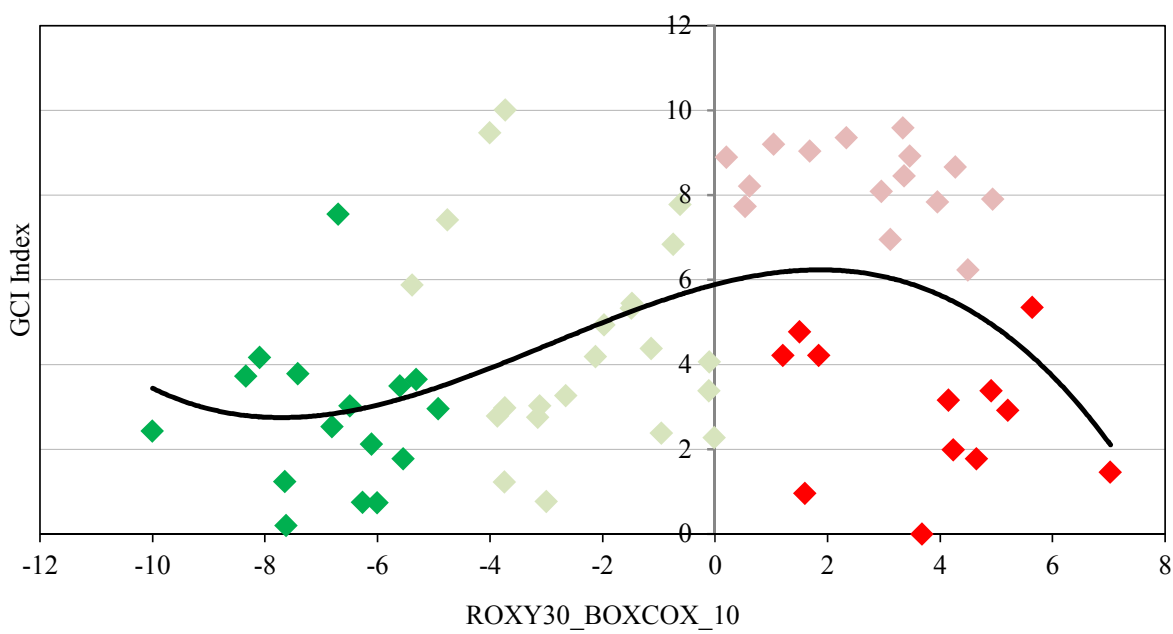

Note: green colour refers to countries where deconcentration is accelerating, light green colour refers to countries where deconcentration is decelerating while red and pink colours represent counties where concentration is accelerating or decelerating, respectively.

Source: own calculation.

\section{The results of ROXY and GEDI examination}

For the analysis, we used both the original index values (ROXY) and the Box-Cox transformed values (ROXY_BOXCOX_10). The original values represented a relatively high level of skewness; hence, the results of their examination should be taken into account with care. The analysis shows that there are positive relationships between the GEDI Index and the different ROXY indexes, but the intensity is moderate. We examined the relationships for the three sub-indexes of GEDI as well (ATT - Entrepreneurial Attitudes, ABT - Entrepreneurial Abilities, ASP - Entrepreneurial Aspirations). The Attitudes subindex has the weakest while the Aspiration has the strongest relationship with ROXY indexes among the sub-indexes (Table 5).

Table 5

The correlation coefficients between the GEDI Index, its sub-indexes and ROXY Index

\begin{tabular}{|c|c|c|c|c|}
\hline $\begin{array}{c}\text { ROXY INDEX } \\
\text { (original and transformed) }\end{array}$ & $\begin{array}{c}\text { GEDI } \\
(\mathrm{AVGCH})\end{array}$ & $\begin{array}{c}\text { ATT } \\
(\mathrm{AVGCH}) \\
\end{array}$ & $\begin{array}{c}\mathrm{ABT} \\
(\mathrm{AVGCH}) \\
\end{array}$ & $\begin{array}{c}\text { ASP } \\
(\mathrm{AVGCH})\end{array}$ \\
\hline ROXY20 & $0.309^{b)}$ & $0.252^{\text {a) }}$ & $0.278^{\text {a) }}$ & $0.334^{\mathrm{b})}$ \\
\hline ROXY20_BOXCOX_10 & $0.277^{\text {a) }}$ & 0.198 & $0.264^{\text {a) }}$ & $0.305^{\text {a) }}$ \\
\hline ROXY30 & $0.328^{\mathrm{b})}$ & $0.279^{\text {a) }}$ & $0.297^{\text {a) }}$ & $0.343^{b)}$ \\
\hline ROXY30_BOXCOX_10 & $0.355^{b)}$ & $0.281^{\text {a) }}$ & $0.353^{b)}$ & $0.358^{b)}$ \\
\hline ROXY40 & $0.310^{b)}$ & $0.246^{a)}$ & $0.284^{\text {a) }}$ & $0.335^{b)}$ \\
\hline ROXY40_BOXCOX_10 & $0.335^{\text {b) }}$ & $0.254^{\text {a) }}$ & $0.316^{\mathrm{b})}$ & $0.360^{b)}$ \\
\hline
\end{tabular}

Notes: ATT = "attitudes", ABT = "abilities, $\mathrm{ASP}=$ "aspirations", $\mathrm{AVG}=$ average, $\mathrm{CH}=$ change

a) Correlation is significant at the 0.05 level (2-tailed). b) Correlation is significant at the 0.01 level (2-tailed). Source: own calculation. 
The analysis indicates the strongest correlation between the ROXY Index and GEDI in the case of ROXY30_BOXCOX_10 $(\mathrm{r}=0.355)$. The lowest results were measured in the case of ROXY20 while the other two ROXY cases have almost the same scores. We can see almost the same results at the sub-indexes. The positive correlation coefficient between the ROXY indexes and GEDI means that the more concentrated the population in a given country's urban system, the better the entrepreneurial performance there. To discover more about the attributes of entrepreneurial aspirations, we analysed the pillars of this subindex as well (Table 6).

The correlation coefficients between the pillars of GEDI Aspiration sub-index and ROXY Index

\begin{tabular}{c|c|c|c}
\hline $\begin{array}{c}\text { Pillars of GEDI } \\
\text { Aspirations sub-index }\end{array}$ & ROXY20_BOXCOX_10 & ROXY30_BOXCOX_10 & ROXY40_BOXCOX_10 \\
\hline ProdInnov_AVG_CH & 0.191 & $0.230^{*}$ & $0.271^{*}$ \\
ProcInnov_AVG_CH & $0.257^{*}$ & $0.270^{*}$ & $0.317^{* *}$ \\
\cline { 2 - 4 } HGrowth_AVG_CH & $0.307^{* *}$ & $0.382^{* *}$ & $0.346^{* *}$ \\
\cline { 2 - 4 } Internation_AVG_CH & $0.268^{*}$ & $0.345^{* *}$ & $0.326^{* *}$ \\
RiskCap_AVG_CH & $0.246^{*}$ & $0.261^{*}$ & $0.261^{*}$
\end{tabular}

Notes: ProdInnov = "product innovation", ProcInnov = "process innovation", HGrowth = "high growth", Internation = "internationalization", RiskCap = "risk capital", $\mathrm{AVG}=$ average, $\mathrm{CH}=$ change

a) Correlation is significant at the 0.05 level (2-tailed). b) Correlation is significant at the 0.01 level (2-tailed).

Source: own calculation.

Almost all of the pillars of the Aspiration sub-index have a significant relationship with the different ROXY indexes, but two pillars are outstanding among them: High growth and Internationalization have the strongest correlation coefficients with the ROXY Index. It means that the high growth (of firm size) and internationalization of firms are relatively dependent on the concentration or deconcentration of a country's population.

The cluster analysis was carried out for each ROXY Index case (cluster analyses with ROXY20 and ROXY40 see the Appendix) with the GEDI Index. We applied the original ROXY Index for this examination. The ROXY30 cases showed the best correlation values with the GEDI Index and its sub-indexes. In this case, we used the data of 65 countries because it was not possible to involve the United Arab Emirates. The first results of cluster analysis helped us to filter the extreme values. There were altogether 7 countries that had extreme positive or negative values (Costa Rica, Dominican Republic, Ecuador, Guatemala, India, Panama and Zambia). Thus, 58 countries have been involved in this cluster analysis (Table 7). 
Results of cluster analysis: ROXY30 and GEDI Index

\begin{tabular}{|c|c|c|c|c|}
\hline Final Cluster Centres & $\begin{array}{c}\text { Cluster } 1 \\
\text { Concentration } \\
\text { with generally } \\
\text { low GEDI } \\
\text { value }\end{array}$ & $\begin{array}{c}\text { Cluster } 2 \\
\text { Acceleration of } \\
\text { concentration } \\
\text { with high } \\
\text { GEDI value }\end{array}$ & $\begin{array}{l}\text { Cluster } 3 \\
\text { Deceleration } \\
\text { of deconcent- } \\
\text { ration with } \\
\text { high GEDI } \\
\text { value }\end{array}$ & $\begin{array}{l}\text { Cluster } 4 \\
\text { Deconcent- } \\
\text { ration with } \\
\text { generally low } \\
\text { GEDI value }\end{array}$ \\
\hline Number of cases & 10 & 18 & 21 & 9 \\
\hline ROXY 30_BOXCOX & 27.76 & 4.24 & -10.31 & -62.66 \\
\hline GEDI & 39.35 & 69.40 & 41.07 & 31.78 \\
\hline $\mathrm{AC}$ & 5 & 5 & 2 & - \\
\hline DC & - & 2 (conc) & - & - \\
\hline DD & 5 (conc) & $\begin{array}{c}6 \text { (conc) } \\
3 \text { (deconc) }\end{array}$ & $\begin{array}{c}16 \text { (deconc) } \\
2 \text { (conc) }\end{array}$ & 6 (deconc) \\
\hline $\mathrm{AD}$ & - & 2 & 1 & 3 \\
\hline
\end{tabular}

Cluster 4 contains those countries whose urban system is characterized by the acceleration of deconcentration or deceleration of deconcentration (but the cases typically remain in the deconcentration stage) represented with a relatively low ROXY30 and GEDI values (GEDI final cluster centre $=31.78$ ). Cluster 3 contains those countries where deconcentration is decelerating, but these countries are mostly still in the deconcentration stage. In this cluster, the GEDI Index is a bit higher than in Cluster 4 (GEDI final cluster centre $=41.07$ ). Those countries have the highest GEDI values that belong to Cluster 2 (GEDI final cluster centre $=69.4$ ). This cluster can be characterized by the acceleration of concentration trends. This cluster contains countries in which the urban system is heading to a concentration from the deconcentration stage. This cluster is a transitional category: it shows the deceleration of deconcentration in counties that have already changed into the concentration stage (DD) or are still in the deconcentration stage (DC). The countries in Cluster 1 have the highest ROXY30 values (final cluster centre $=27.76$ ), but their GEDI values (final cluster centre $=39.35$ ) are lower than countries in Cluster 2 .

These results mean that those countries that show deconcentration trends have lower GEDI values than other countries characterized by concentration. However, this does not mean an obvious nexus between concentration and high entrepreneurial performance. It seems that concentration of the population has a positive effect on entrepreneurship, but on the other hand, there is a threshold and after that, further concentration of the population may not improve the entrepreneurial performance, but has a negative effect on it (Figure 2). 
The connection between the GEDI scores and ROXY30

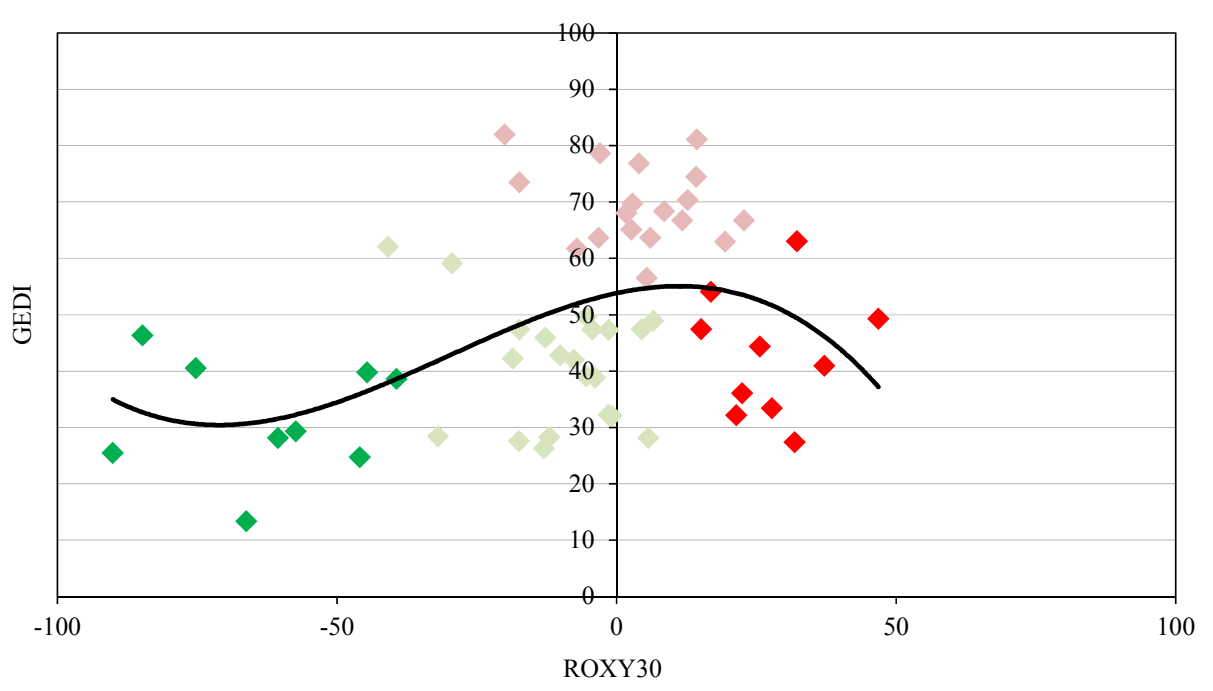

Note: green colour refers to countries where deconcentration is accelerating, light green colour refers to countries where deconcentration is decelerating while red and pink colours refer to counties where concentration is accelerating or decelerating, respectively.

Source: own calculation.

\section{Conclusions}

The correlation analyses confirmed that the more concentrated the population within a country's urban system, the higher its competitiveness and entrepreneurial performance. This result seemingly supports the "bigger is better" concept. The correlation analysis has shown that the concentration or deconcentration of the population is only one important factor in the explanation of countries' entrepreneurial performance and competitiveness. This has been proven by the moderate correlation coefficients between the GCI/GEDI and ROXY indexes (both original and transferred). Consequently, we should consider that other effects may exist (e.g. differences in institutional settings, creativity and openness of human resources, culture).

However, in-depth analysis (conducting cluster analyses) confirmed that relatively high-levels of concentration or deconcentration within an urban system are coupled with lower GCI/GEDI values. Those countries have the highest GCI/GEDI values that have a ROXY Index value close to zero. It means that they have a moderate level of concentration (positive ROXY values) or moderate level of deconcentration (negative ROXY values). Our analysis indicates that, initially, as concentration increases (or deconcentration decreases) competitiveness and entrepreneurial performance also increase, but at a decreasing rate. Both of them eventually reaches a maximum and then after a certain point decrease with further concentration. Therefore, the curve that apprehends this relationship is non-linear and folding back. As follows, our results support the view that concentration is useful until a certain threshold, but excessive concentration could not help to improve 
competitiveness or entrepreneurial performance. In other words, this indicates that underor over-concentration of the population within an urban system is not a useful phenomenon considering competitiveness or entrepreneurial performance.

\section{REFERENCES}

Acs, Z. J.-Armington, C. (2004): Employment growth and entrepreneurial activity in cities Regional Studies 38 (8): 911-927.

Acs, Z.-Autio, E.-Szerb, L. (2014): National Systems of Entrepreneurship: Measurement issues and policy implications Research Policy 43 (3): 476-494.

Acs, Z.-Varga, A. (2002): Geography, Endogenous Growth, and Innovation International Regional Science Review 25 (1): 132-148.

Annoni, P.-Kozovska, K. (2010): EU Regional Competitiveness Index 2010 JRC Scientific and Technical Reports, European Commission Joint Research Centre Institute for Security and Protection of the Citizens, Luxemburg.

Castells, M. (1996): The rise of the network society Blackwell, Oxford.

Castells-Quintana, D.-Royuela, V. (2014): Agglomeration, inequality and economic growth Annual Regional Science 52 (2): 343-366.

Chinitz, B. (1961): Contrasts in Agglomeration: New York and Pittsburgh. American Economic Review 51 (2): 279-289.

Ciccone, A. (2002): Agglomeration Effects in Europe. European Economic Review 46 (2): 213-227.

Ciccone, A. -Hall, R. (1996): Productivity and the density of economic activity American Economic Review 86 (1): 54-70.

Czaller, L. (2012): A Zipf-törvény érvényesülése a világ országaiban Területi Statisztika 52 (5): 461-478.

David, Q.-Peeters, D.-Van Hamme, G.-Vandermotten, C. (2013): Is bigger better? Economic performances of European cities, 1960-2009 Cities 35: 237-254.

Duranton, G.-Puga, D. (2004): Micro-foundations of urban agglomeration economies. In: Henderson, J. V. Thisse, J. F. (eds.): Handbook of Regional and Urban Economics, Edition1, Chapter 48, pp. $2063-$ 2117., Elsevier, Amsterdam

Duranton, G.-Puga, D. (2001): Nursery Cities American Economic Review 91 (5): 1457-1477.

Eeckhout, J. (2004): Gibrat's Law for (All) Cities The American Economic Review 94 (5): 1429-1451.

Ellison, G -Glaeser, E. L. (1997): Geographic concentration in US manufacturing industries: A dartboard approach Journal of Political Economy 105 (5): 889-927.

Gabaix, X. (1999): Zipf's Law for Cities: An Explanation The Quarterly Journal of Economics 114 (3): 739 767.

Glaeser, E. L.-Kallal, H.-Scheinkman, J.-Shleiter, A. (1992): Growth in the Cities. Journal of Political Economy 100 (6): 1126-1152.

Henderson, J. V. (2003a): Marshall's Scale Economies Journal of Urban Economies 53 (1): 1-28.

Henderson, J. V. (2003b): The Urbanization Process and Economic Growth: The So-What Question. Journal of Economic Growth 8 (1): 47-71.

Hirvonen, M.-Hiraoka, N.-Kawashima, T. (1997): Long-term Urban Development of the Finnish Population: Application of the ROXY-index Analytical Method Gakushuin Economic Papers 36 (2): 243-263.

Kawashima, T. (1978): Recent Urban Evolution Processes in Japan: Analysis of Functional Urban Regions. Presented at the 25th North American Meeting of the Regional Science Association, Chicago, Illinois, USA.

Kawashima, T. (1982): Recent urban trends in Japan: analysis of functional urban regions. In: Kawashima, T. Korcelli, P. (eds.): Human settlement systems: spatial patterns and trends, pp. 21-40., International Institute for Applied Systems Analysis, Laxenburg.

Kawashima, T. (1985): Roxy Index: An Indicative Instrument to Measure the Speed of Spatial Concentration and Deconcentration of Population Gakushuin Economic Papers 22 (2): 183-213.

Kawashima, T. (1986), People Follow Jobs in Japan?: Suburbanization of Labour and Job Markets Gakushuin Economic Papers 23 (1-2): 157-183. 
Kawashima, T.-Azis, I.-Tane, M. (1997): Comparative analysis of intercity agglomeration http:/www.econbiz.de/Record/comparative-analysis-of-intercity-agglomeration-kawashimatatsuhiko/10001297129 [downloaded: 1st February 2014]

Knoben, J.-Ponds R.-van Oort, F. (2011): Employment from new firm formation in the Netherlands: Agglomeration economies and the Knowledge Spillover Theory of Entrepreneurship Entrepreneurship \& Regional Development 23 (3-4): 135-157.

Fukatsu, A.-Kawashima, T. (1999): Urbanization, Suburbanization and Revived-urbanization: ROXY-index Analysis for the Chou-line Region of Tokyo Gakushuin Economic Papers 36 (3): 389-414.

Klaassen, L. H.-Paelinck, J. H. P. (1979): The Future of Large Towns. Environment and Planning A 11 (10): 1095-1104.

Klaassen, L. H.-Bourdrez, J. A. et al. (1981): Transport and Reurbanization, Gower, Aldershot.

Krugman, P. (1991): Increasing returns and economic geography Journal of Political Economy 99 (3): $483-499$.

Krugman, P. (2009): The Increasing Returns Revolution in Trade and Geography The American Economic Review 99 (3): 561-571.

Marshall, A. (1920): Principles of Economics. Macmillan and Co., Ltd., London.

McCann, P.-Acs, J. Z. (2012): Globalization: Countries, cities and multinationals Regional Studies 45 (1): $17-$ 32.

McCann, P. (2013): Modern Urban and Regional Economics. Oxford University Press, London.

Parr, J. B. (2002): Agglomeration economies: ambiguities and confusions Environment and Planning A 34 (4): $717-731$.

Puga, D. (2010): The magnitude and causes of agglomeration economies Journal of Regional Science 50 (1): 203-219.

Reynolds, P.D.-Storey, D.J.-Westhead, P. (1994): Cross-national comparisons of the variation in new firm formation rates Regional Studies 28 (4): 443-456.

Rizov, M.-Oskamb, A.-Walshc, P. (2012): Is there a limit to agglomeration? Evidence from productivity of Dutch firms Regional Science and Urban Economics 42 (4): 595-606.

Rosenthal, S. S.-Strange, W. C. (2003): Geography, industrial organization and agglomeration. Review of Economics and Statistics 85 (2): 377-393.

Rosenthal, S. S.-Strange, W. C. (2004): Evidence on the nature and sources of agglomeration economies. In: Henderson, J. V., Thisse, J. F. (eds.): Handbook of Regional and Urban Economics, Edition 1, Chapter 49, pp. 2119-2171., Elsevier, Amsterdam.

Schwab, K. (ed.) (2013): The Global Competitiveness Report. World Economic Forum. http://www3.weforum.org/docs/WEF_GlobalCompetitivenessReport_2013-14.pdf [downloaded: 1st March 2014]

Szerb, L-Ács, Z.-Aidis, R. (2013): A comparative analysis of Hungary's entrepreneurial performance in the 2006-2010 time period based in the GEM and the GEDI methodologies. Pécsi Tudományegyetem Közgazdaságtudományi Kar, Pécs.

Tabuchi, T.-Thisse, J.-Zeng, D. (2005): On the number and size of cities Journal of Economic Geography 5 (4): $423-448$.

Van Stel, A.-Suddle, K. (2008): The impact of new firm formation on regional development in the Netherlands Small Business Economics 30 (1): 31-47.

Vreeker, R.-Deakin, M.-Curwell, S. (eds.) (2009): Sustainable Urban Development, Volume 3: The Toolkit for Assessment. Routledge: New York. 


\section{Appendix}

The length of examined periods

Table A1

\begin{tabular}{|c|c|c|c|c|c|}
\hline Country & Period (t) & Period (t-1) & Country & Period (t) & Period ( $(-1)$ \\
\hline Algeria & 2008/1998 & $1998 / 1987$ & Jordan & $2004 / 1994$ & no results \\
\hline Argentina & $2010 / 2001$ & 2001/1991 & Kazakhstan & $2012 / 1999$ & $1999 / 1989$ \\
\hline Australia & $2011 / 2006$ & $2006 / 2001$ & Korea & $2012 / 2002$ & $2002 / 1997$ \\
\hline Austria & $2013 / 2001$ & $2001 / 1991$ & Latvia & $2013 / 2000$ & $2000 / 1989$ \\
\hline Bangladesh & $2011 / 2001$ & $2001 / 1991$ & Macedonia & $2010 / 2002$ & $2002 / 1994$ \\
\hline Belgium & $2013 / 2000$ & $2000 / 1990$ & Malaysia & $2000 / 1991$ & no results \\
\hline Bolivia & $2010 / 2001$ & $2001 / 1992$ & Mexico & $2010 / 2005$ & $2005 / 2000$ \\
\hline Bosnia Herzegovina & $2013 / 1991$ & $1991 / 1981$ & Montenegro & $2011 / 2003$ & $2003 / 1991$ \\
\hline Brazil & $2010 / 2000$ & $2000 / 1991$ & Morocco & $2004 / 1994$ & $1994 / 1982$ \\
\hline Canada & $2011 / 2006$ & $2001 / 1996$ & The Netherlands & $2013 / 2000$ & $2000 / 1990$ \\
\hline Chile & $2012 / 2002$ & $2002 / 1992$ & Norway & $2013 / 2000$ & $2000 / 1990$ \\
\hline China & $2010 / 2000$ & $2000 / 1990$ & Panama & $2010 / 2000$ & $2000 / 1990$ \\
\hline Colombia & $2010 / 2005$ & $2005 / 1993$ & Peru & $2007 / 1993$ & $1993 / 1981$ \\
\hline Costa Rica & $2011 / 2000$ & $2000 / 1984$ & Philippines & $2010 / 2000$ & $2000 / 1990$ \\
\hline Croatia & $2011 / 2001$ & $2001 / 1991$ & Poland & $2012 / 2002$ & $2002 / 1992$ \\
\hline Czech Rep & $2011 / 2001$ & $2001 / 1991$ & Portugal & $2011 / 2001$ & no results \\
\hline Denmark & $2013 / 2000$ & $2000 / 1990$ & Puerto Rico & $2010 / 2000$ & $2000 / 1990$ \\
\hline Dominican Rep & $2010 / 2002$ & $2002 / 1993$ & Romania & $2011 / 2002$ & $2002 / 1992$ \\
\hline Ecuador & $2010 / 2001$ & $2001 / 1990$ & Russia & $2013 / 2002$ & $2002 / 1989$ \\
\hline Egypt & 2006/1996 & $1996 / 1986$ & Saudi Arabia & $2010 / 2004$ & $2004 / 1992$ \\
\hline Finland & $2012 / 2000$ & $2000 / 1990$ & Serbia & $2011 / 2002$ & $2002 / 1991$ \\
\hline France & $2011 / 2006$ & 2006/1999 & Slovakia & $2012 / 2001$ & $2001 / 1991$ \\
\hline Germany & $2012 / 2001$ & $2001 / 1995$ & Slovenia & $2013 / 2002$ & $2002 / 1991$ \\
\hline Ghana & $2010 / 2000$ & $2000 / 1996$ & South Africa & $2011 / 2001$ & no results \\
\hline Greece & $2011 / 2001$ & $2001 / 1991$ & Spain & $2013 / 2001$ & $2001 / 1991$ \\
\hline Guatemala & $2008 / 2002$ & $2002 / 1994$ & Sweden & $2012 / 2005$ & $2005 / 2000$ \\
\hline Hungary & $2013 / 2001$ & $2001 / 1990$ & Switzerland & $2012 / 2000$ & $2000 / 1990$ \\
\hline Iceland & $2013 / 2005$ & $2005 / 2000$ & Taiwan & $2012 / 2006$ & $2006 / 2001$ \\
\hline India & $2011 / 2001$ & $2001 / 1991$ & Uganda & $2011 / 2002$ & $2002 / 1991$ \\
\hline Iran & $2011 / 2006$ & $2006 / 1996$ & UAE & $2005 / 1995$ & $1995 / 1985$ \\
\hline Ireland & $2011 / 2006$ & $2006 / 2002$ & United Kingdom & $2011 / 2001$ & $2001 / 1991$ \\
\hline Israel & $2012 / 2008$ & $2008 / 1995$ & United States & $2012 / 2000$ & $2000 / 1990$ \\
\hline Italy & $2012 / 2001$ & $2001 / 1991$ & Uruguay & $2011 / 2004$ & $2004 / 1996$ \\
\hline Jamaica & $2011 / 2001$ & $2001 / 1991$ & Venezuela & $2011 / 2001$ & $2001 / 1990$ \\
\hline Japan & $2010 / 2005$ & $2005 / 2000$ & Zambia & $2010 / 2000$ & $2000 / 1990$ \\
\hline
\end{tabular}

Source: edited by the authors. 
Results of the cluster analysis: ROXY20 - GCI index

\begin{tabular}{|c|c|c|c|c|}
\hline $\begin{array}{l}\text { Final Cluster } \\
\text { Centres }\end{array}$ & $\begin{array}{c}\text { Cluster } 1 \\
\text { Concentration with } \\
\text { generally high } \\
\text { GCI value }\end{array}$ & \multicolumn{2}{|c|}{$\begin{array}{c}\text { Cluster } 2 \\
\text { Deceleration of } \\
\text { deconcentration, with } \\
\text { GCI values higher } \\
\text { than the average }\end{array}$} & $\begin{array}{c}\text { Cluster } 3 \\
\text { Deconcentration, } \\
\text { with generally low } \\
\text { GCI values }\end{array}$ \\
\hline Number of cases & 33 & \multicolumn{2}{|c|}{20} & 10 \\
\hline ROXY 20 & 15.10 & \multicolumn{2}{|c|}{-17.43} & -82.13 \\
\hline GCI & 5.58 & \multicolumn{2}{|c|}{4.60} & 2.61 \\
\hline $\mathrm{AC}$ & 9 & \multicolumn{2}{|c|}{-} & - \\
\hline DC & 2 (conc/deconc) & \multicolumn{2}{|c|}{1 (deconc) } & 2 (deconc) \\
\hline DD & 22 (conc) & \multicolumn{2}{|c|}{18 (deconc) } & 3 \\
\hline $\mathrm{AD}$ & - & \multicolumn{2}{|c|}{1} & 5 (deconc) \\
\hline Final Cluster Centres & $\begin{array}{l}\text { Cluster } 1 \\
\text { Concentration } \\
\text { with generally } \\
\text { low GCI value }\end{array}$ & $\begin{array}{l}\text { Cluster } 2 \\
\text { Acceleration of } \\
\text { concentration } \\
\text { with high GCI } \\
\text { value }\end{array}$ & $\begin{array}{r}\mathrm{Cl} \\
\text { Dece } \\
\text { decon } \\
\text { with } \\
\mathrm{V}\end{array}$ & $\begin{array}{l}\text { Cluster } 4 \\
\text { Deconcent- } \\
\text { ration with } \\
\text { generally low } \\
\text { GCI value }\end{array}$ \\
\hline Number of cases & 18 & 18 & & 22 \\
\hline ROXY 20_BOXCOX & 4.35 & 4.69 & & -5.81 \\
\hline GCI & 2.78 & 7.62 & & 2.49 \\
\hline $\mathrm{AC}$ & 6 & 4 & & - \\
\hline $\mathrm{DC}$ & 1 (deconc) & 2 (conc) & & 2 (deconc) \\
\hline DD & 11 (conc) & 12 (conc) & $7(c$ & 13 (deconc) \\
\hline $\mathrm{AD}$ & - & - & & 7 \\
\hline
\end{tabular}

Notes: $\mathbf{A C}=$ Acceleration of concentration. DC (deconc) $=$ Deceleration of concentration and it has already changed to deconcentration stage. DC (conc) = Deceleration of concentration, but it is still in concentration stage. DD (deconc) = Deceleration of deconcentration, but it is still in deconcentration stage. DD (conc) $=$ Deceleration of deconcentration and it has already changed to concentration stage. $\mathbf{A D}=$ Acceleration of deconcentration.

Source: own calculation. 


\section{The connection between GCI scores and ROXY20_BOXCOX}

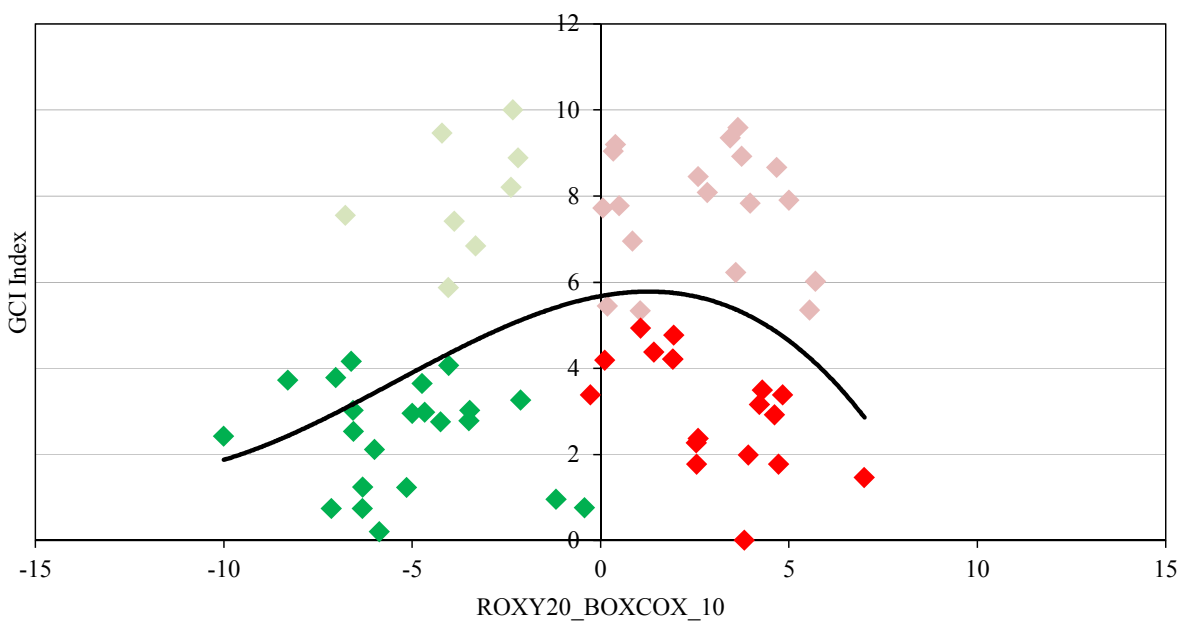

Note: green colour refers to countries where deconcentration is accelerating, light green colour refers to countries where deconcentration is decelerating while red and pink colours refer to counties where concentration is accelerating or decelerating, respectively.

Source: own calculation.

Table A3

Results of the cluster analysis: ROXY40 - GCI index

\begin{tabular}{|c|c|c|c|}
\hline $\begin{array}{c}\text { Final Cluster } \\
\text { Centres }\end{array}$ & $\begin{array}{c}\text { Cluster } 1 \\
\text { Concentration with } \\
\text { generally high } \\
\text { GCI value }\end{array}$ & $\begin{array}{c}\text { Cluster } 2 \\
\text { Deceleration of } \\
\text { deconcentration, with } \\
\text { GCI values higher } \\
\text { than the average }\end{array}$ & $\begin{array}{c}\text { Cluster } 3 \\
\text { Deconcentration, } \\
\text { with generally low } \\
\text { GCI values }\end{array}$ \\
\hline Number of cases & 26 & 28 & 8 \\
\hline ROXY 40 & 16.38 & -21.28 & -96.10 \\
\hline GCI & 6.12 & 4.03 & 3.03 \\
\hline $\mathrm{AC}$ & 10 & - & - \\
\hline $\mathrm{DC}$ & 4 (conc) & - & 1 (deconc) \\
\hline DD & 12 (conc) & 24 (deconc) & 1 (deconc) \\
\hline $\mathrm{AD}$ & - & 4 & 6 \\
\hline
\end{tabular}




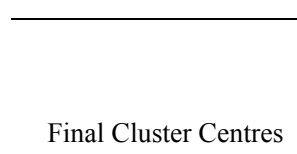

Cluster Centres

\begin{tabular}{lc} 
& low GCI value \\
\hline Number of cases & 12
\end{tabular}

ROXY 40_BOXCOX

GCI

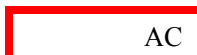

\begin{tabular}{|l|}
\hline DC \\
\hline DD \\
\hline
\end{tabular}

AD

\section{Cluster 1}

Concentration with generally

low GCI value

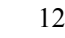

4.64

2.96

5

1 (conc)

6 (conc)
3 (conc)

1 (deconc)

8 (deconc)

3

Notes: same as in Table 3 and Table 4.

Source: own calculation.

The connection between GCI scores and ROXY40_BOXCOX

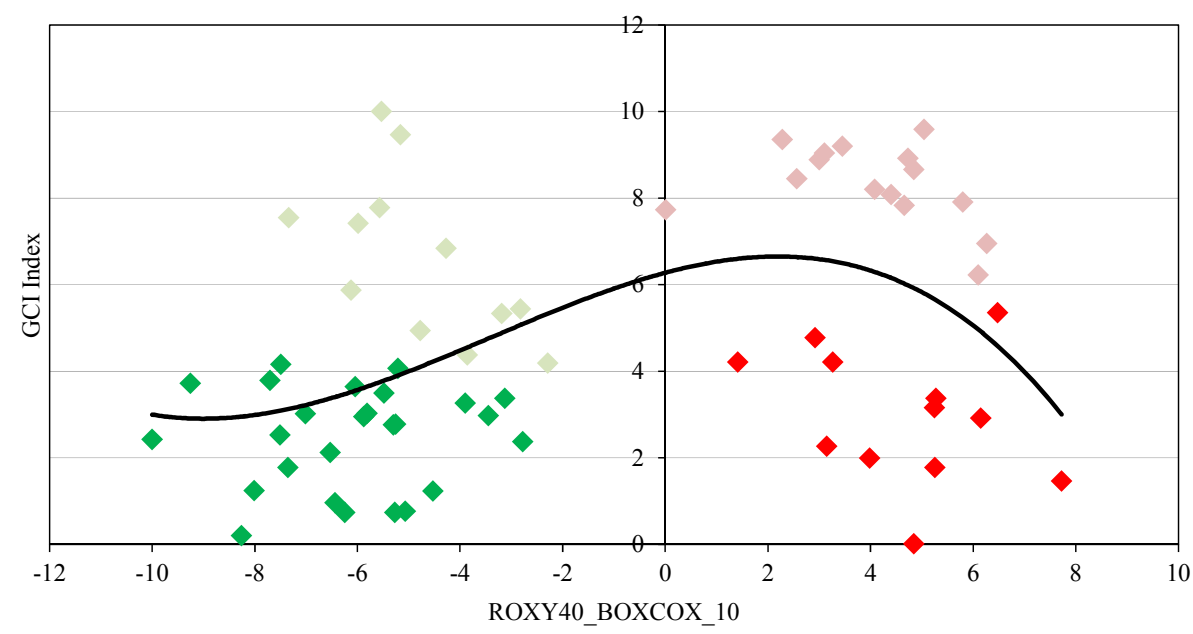

Note: green colour refers to countries where deconcentration is accelerating, light green colour refers to countries where deconcentration is decelerating while red and pink colours refer to counties where concentration is accelerating or decelerating, respectively.

Source: own calculation.
(Continued)

\section{Cluster 4}

Deconcent-

ration with

generally low

GCI value

$$
26
$$

$-6.11$

2.47

Figure A2 


\section{Results of cluster analysis: ROXY20 - GEDI Index}

\begin{tabular}{|c|c|}
\hline Final Cluster Centres & $\begin{array}{c}\text { Cluster } 1 \\
\text { Concentration } \\
\text { with generally } \\
\text { lower GCI } \\
\text { value }\end{array}$ \\
\hline
\end{tabular}

Number of cases ROXY 40_BOXCOX GEDI

\begin{tabular}{|c|}
\hline $\mathrm{AC}$ \\
\hline $\mathrm{DC}$ \\
\hline
\end{tabular}

DD

DD

3 (deconc)

$\mathrm{AD}$
14 (conc),

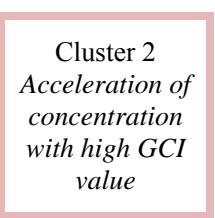

20

1.16

68.52

40.04

6

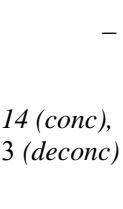

2 (conc)

8 (conc), 7
(deconc)

Cluster 3
Deceleration
of deconcent-
ration, with
high GCI
value

11

$-26.58$

36.66

1 (deconc)

2 (deconc)

8 (deconc)

3 (deconc)
Cluster 4

Deconcent-

ration, with

generally low

GCI value

9

Notes: $\mathbf{A C}=$ Acceleration of concentration. DC (deconc) $=$ Deceleration of concentration and it has already changed to deconcentration stage. DC (conc) = Deceleration of concentration, but it is still in concentration stage. DD (deconc) = Deceleration of deconcentration, but it is still in deconcentration stage. DD (conc) = Deceleration of deconcentration and it has already changed to concentration stage. $\mathbf{A D}=$ Acceleration of deconcentration.

Source: own calculation.

The connection between the GEDI scores and ROXY20

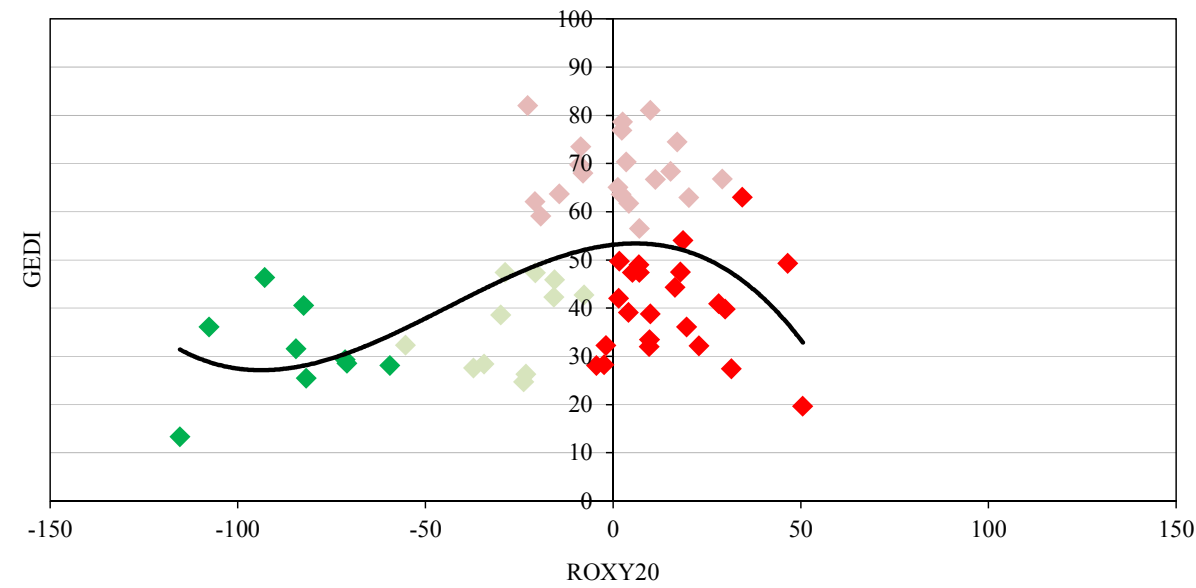

Note: green colour refers to countries where deconcentration is accelerating, light green colour refers to countries where deconcentration is decelerating while red and pink colours refer to counties where concentration is accelerating or decelerating, respectively.

Source: own calculation. 
Results of cluster analysis: ROXY40 and GEDI Index

Number of cases

GEDI

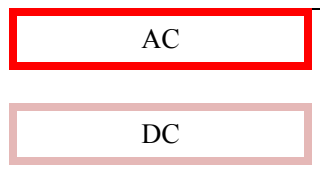

\begin{tabular}{c} 
Cluster 1 \\
Final Cluster Centres \\
Concentration \\
with generally \\
lower GCI \\
value \\
\hline
\end{tabular}
ROXY 40_BOXCOX

DD

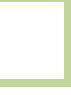

6 (conc)

14

22.31

42.29

6

2 (deconc)

3 (deconc)

21 (deconc)

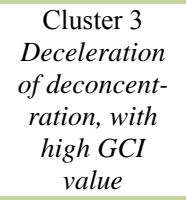

22

$-22.27$

37.21

68.26

2 (conc)

3

Source: own calculation.

Figure 6
Cluster 4

Deconcent-

ration, with

generally low

GCI value

7

$-88.71$

35.45

(conc)

(conc)

5

The connection between the GEDI scores and ROXY40

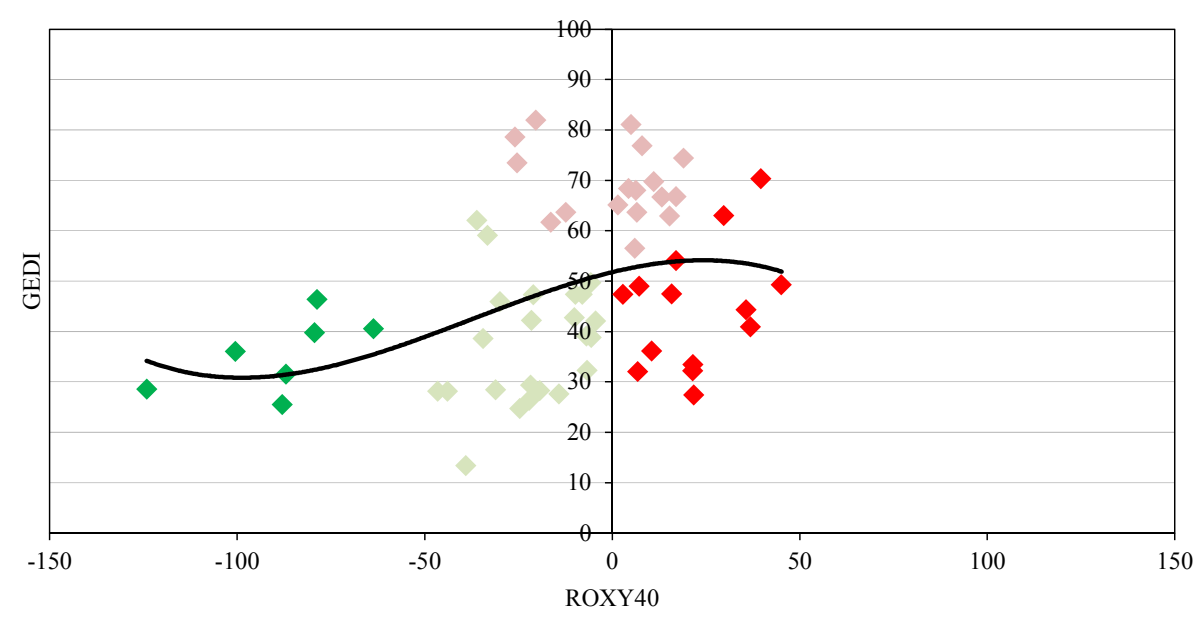

Source: own computation. 
Appendix 3

Table 13

The results of cluster analysis between ROXY Indexes and GCI Index

\begin{tabular}{l|r|r|r|r|r|r}
\hline \multirow{2}{*}{ ANOVA } & \multicolumn{2}{|c|}{ Cluster } & \multicolumn{2}{c|}{ Error } & \multirow{2}{*}{ F } & Sig. \\
\cline { 2 - 6 } & \multicolumn{1}{c|}{$\begin{array}{c}\text { Mean } \\
\text { Square }\end{array}$} & df & $\begin{array}{c}\text { Mean } \\
\text { Square }\end{array}$ & df & & \\
\hline ROXY_20 & 36945,376 & 2 & 181,007 & 60 & 204,110 &, 000 \\
GCI_AVE_CH_10 & 34,468 & 2 & 7,247 & 60 & 4,756 &, 012 \\
ROXY_20_BOXCOX_10 & 523,973 & 3 & 3,277 & 62 & 159,916 &, 000 \\
GCI_AVE_CH_10 & 136,622 & 3 & 1,772 & 62 & 77,086 &, 000 \\
ROXY_30_BOXCOX_10 & 465,608 & 3 & 1,431 & 61 & 325,341 &, 000 \\
GCI_AVE_CH_10 & 100,020 & 3 & 3,593 & 61 & 27,841 &, 000 \\
ROXY_40 & 39659,711 & 2 & 220,599 & 59 & 179,782 &, 000 \\
GCI_AVE_CH_10 & 43,303 & 2 & 7,044 & 59 & 6,147 &, 004 \\
ROXY_40_BOXCOX_10 & 529,564 & 3 & 2,936 & 61 & 180,339 &, 000 \\
GCI_AVE_CH_10 & 135,866 & 3 & 1,830 & 61 & 74,261 &, 000
\end{tabular}

Table 14

The results of cluster analysis between ROXY Indexes and GEDI Index

\begin{tabular}{l|r|r|r|r|r|r}
\hline \multirow{2}{*}{ ANOVA } & \multicolumn{2}{c|}{ Cluster } & \multicolumn{2}{c|}{ Error } & \multirow{2}{*}{ F } & Sig. \\
\cline { 2 - 6 } & $\begin{array}{c}\text { Mean } \\
\text { Square }\end{array}$ & df & $\begin{array}{c}\text { Mean } \\
\text { Square }\end{array}$ & df & & \\
\hline ROXY20 & 23860,079 & 3 & 223,237 & 59 & 106,882 &, 000 \\
GEDI_AVGCH & 4616,308 & 3 & 81,006 & 59 & 56,987 &, 000 \\
ROXY30 & 14152,718 & 3 & 162,240 & 54 & 87,233 &, 000 \\
GEDI_AVGCH & 4123,310 & 3 & 96,702 & 54 & 42,639 &, 000 \\
ROXY40 & 20903,343 & 3 & 205,731 & 57 & 101,605 &, 000 \\
GEDI_AVGCH & 3827,858 & 3 & 120,616 & 57 & 31,736 &, 000
\end{tabular}

